\section{Australia launches global carbon-capture institute}

Australian prime minister Kevin Rudd last week launched a government-funded initiative to coordinate and accelerate largescale carbon capture and storage (CCS) projects worldwide.

The Global Carbon Capture and Storage Institute (GCCSI), based in Canberra, will "galvanize global efforts to demonstrate and deploy CCS”, Rudd said on 16 April. Australia is the world's leading exporter of coal and a big user of the fossil fuel, and will fund the GCCSI with up to Aus $\$ 100$ million (US\$70.6 million) a year. Support for the public-private partnership has already been pledged by around 20 governments and more than 40 industrial companies.

GCCSI head Nick Otter said that the institute's first task would be to assess the state of mooted large-scale CCS projects around the world - financing for many of which has been derailed following the global economic downturn - in preparation for G8 discussions in Sardinia in July. For a longer version of this story, see http://tinyurl.com/d4a4ux.

\section{Company offering ethical reviews suspends activity}

A US company that provides ethical reviews of clinical trials agreed to halt operations after being warned by the US Food and Drug Administration (FDA) about violating federal guidelines.

The company, Coast IRB of Colorado Springs, Colorado, was ensnared by a governmental investigation unveiled before Congress last month (see Nature 458, 557; 2009). Investigators submitted a fictitious clinical-trial protocol to three independent institutional review boards. Two boards rejected the protocol, with one member calling it "the riskiest thing I've ever seen on this board". But Coast IRB voted unanimously to approve the trial.

On 14 April, the FDA announced that Coast IRB would not approve new studies or add additional subjects to ongoing studies until the agency was satisfied that the company had corrected its procedures. The company has been warned by the FDA before, in 2008, for inappropriately expediting review of a clinical-trial protocol.

\section{US and Japan to collaborate on stem-cell technology}

Rumours of a potential conflict over the exploitation of patents for induced pluripotent stem cell (iPS) technology were put to rest last week.

\title{
Germany joins in with maize moratorium
}

\section{Germany last week banned the} cultivation of Monsanto's genetically modified maize (corn), MON810 the only transgenic crop approved for cultivation in the European Union (EU). It joins five other countries - France, Austria, Greece, Hungary and Luxembourg - that have outlawed the US firm's pestresistant maize despite its approval under a legally binding EU directive (see Nature 457, 946-947; 2009).

\section{Ilse Aigner, Germany's federal}

agricultural minister, announced the ban

on 14 April, just days before the crop

would have been sown. Research minister Annette Schavan called the decision "regrettable".

The European Commission says it is analysing the situation. So far, it has not succeeded in forcing the other EU countries to reverse their bans because it cannot muster the required level of support from its 27 member states.

For a longer version of this story, see http://tinyurl.com/maizeban.

IPS technology was pioneered in 2006 by Shinya Yamanaka of Japan's Kyoto University. By early 2008, Kazuhiro Sakurada, who had also been working on iPS technologies at the Kobe-based drug company Bayer Yakuhin, left Japan to head research at iZumi Bio - a biotech firm focused on commercializing iPS technology in San Francisco, California. Last spring, Japanese newspapers warned that Sakurada might try to claim patent rights to the technology, which can turn ordinary cells into an embryonic-like state that could be useful for research and therapy (see Nature 453, 962-963; 2008).

But on 14 April, iZumi Bio announced a collaboration with Kyoto University to develop methods for using iPS technologies for drug discovery and therapy.

\section{Jailed Iranian AIDS doctors lose court appeal}

A court in Iran has rejected an appeal by the two Iranian HIV researchers charged with collaborating with the United States to overthrow the government.

Physicians Kamiar Alaei and his brother Arash Alaei were sentenced to prison terms of three and six years, respectively, in

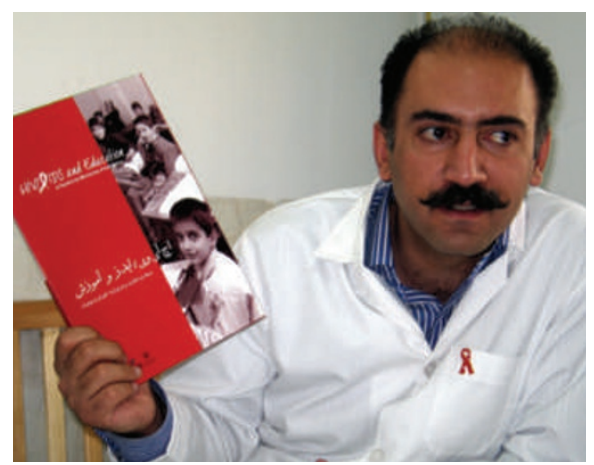

Arash Alaei will remain in prison after his appeal was rejected.
December 2008 (see Nature 457, 517; 2009). The court rejected their appeal on 18 March but the news became public only last week.

The brothers' trial and convictions have been widely condemned by human-rights groups. Their lawyer, Masoud Shafie, intends to make a final appeal by 7 May to Iran's judiciary chief, Ayatollah Mahmoud Hashemi Shahrudi.

A 'Global Day of Action' in support of the Alaeis will be held on 12 May and is likely to include vigils at Iranian embassies worldwide.

\section{US medical institute invests in undergraduates}

The Howard Hughes Medical Institute (HHMI) is offering up to $\$ 85$ million in grants to further undergraduate science education at the United States' top research universities.

The HHMI, which is the largest private funder of biomedical research in the United States, last year dedicated $\$ 60$ million for science teaching at liberal arts colleges. Now, the institute is awarding individual grants of up to $\$ 2.2$ million over 4 years for proposals from 197 of the nation's most research-intensive institutions.

Schools must register their interest by 14 May, but have until 1 October to apply for the grants, which should focus on student research, faculty development, curriculum development or community outreach.

As a supplement to these institutional grants, applicants may also compete for awards of up to $\$ 600,000$ to test experimental approaches to tackling specific science education challenges. "We want to encourage faculty to try new things," says David Asai, director of the HHMI's undergraduate grants programme. "It's hard to anticipate the kinds of ideas that may come forward." 